\title{
WYNIKI APLIKACJI METODY SKŁADANEK MATERIAŁÓW KRZEMIENNYCH ZE STANOWISKA ŻUŁAWKA 13, GM. WYRZYSK, POW. PILSKI
}

\section{THE RESULTS OF APPLICATION OF REFITTING METHOD TO THE FLINT MATERIALS FROM ŻUŁAWKA, SITE 13, COM. WYRZYSK, COUNTY PIŁA}

\author{
Maciej Kaczor \\ Instytut Archeologii. Uniwersytet im. Adama Mickiewicza w Poznaniu \\ ul. Umultowska 89D, 61-614 Poznań, Polska \\ maciejkaczor0306@o2.pl
}

\begin{abstract}
ABSTRCT: The article presents the results of the analysis of Świderian culture materials from Żuławka, site 13, com. Wyrzysk, with the refitting method applied. The refitting blocks have been analysed twice, from different points of view. The first study, in 2003, concentrated on spatial relations between areas of activities, while the second analysed technological aspects. The article aims to present unpublished results of the study.
\end{abstract}

KEY WORDS: Final Paleolithic, Swiderian Culture, Refitting method, Lithic technology, Camp site organisation

\section{WSTEP}

Problematyka użycia metody składanek w badaniach technologii krzemieniarstwa świderskiego doczekała się wielu prac badawczych (m.in.: Dziewanowski, 2006; Grużdź i in., 2012; Fiedorczuk, 1992). Również kwestie analizy rejonów aktywności na stanowiskach ma bogatą literaturę (m.in.: Chichocki, 2003; Fiedorczuk, 2006, 2014). Najbardziej kompleksowo przebadano dotychczas centralną część kompleksu, 
za którą uznaję obszar o dużym udziale krzemienia czekoladowego w inwentarzach, czyli grupy II wg Szymczaka (2000). Tereny rubieżowe kultury świderskiej, jak i całego technokompleksu $\mathrm{z}$ liściakami $\mathrm{w}$ ostatnich latach również doczekały się kilku opracowań (m.in.: Przeździecki, 2014; Rakoca, 2013, 2015). Jednym z przebadanych w ostatnich latach takich stanowisk jest Żuławka 13 (ryc. 1) położona nad środkowym biegiem Noteci. Materiał z niego poddawany był dotąd dwukrotnie badaniom przy użyciu metody składanek, $w$ obu przypadkach służył on do realizacji prac magisterskich (Cichocki, 2003; Kaczor, 2017). Artykuł ten jest wyciągiem z nich, opis i analiza przedstawiona zostanie w wersji skróconej (wybór najbardziej dystynktywnych bloków). W interpretacji natomiast wykorzystane zostaną już wszystkie materiały, które udało się złożyć. Głównym celem więc będzie publikacja wyników obu analiz, które powinny zaistnieć w formie ogólnodostępnej dla możliwości dalszego rozwoju badań nad problematyką krzemieniarstwa, jak i modeli osadnictwa świderskiego.

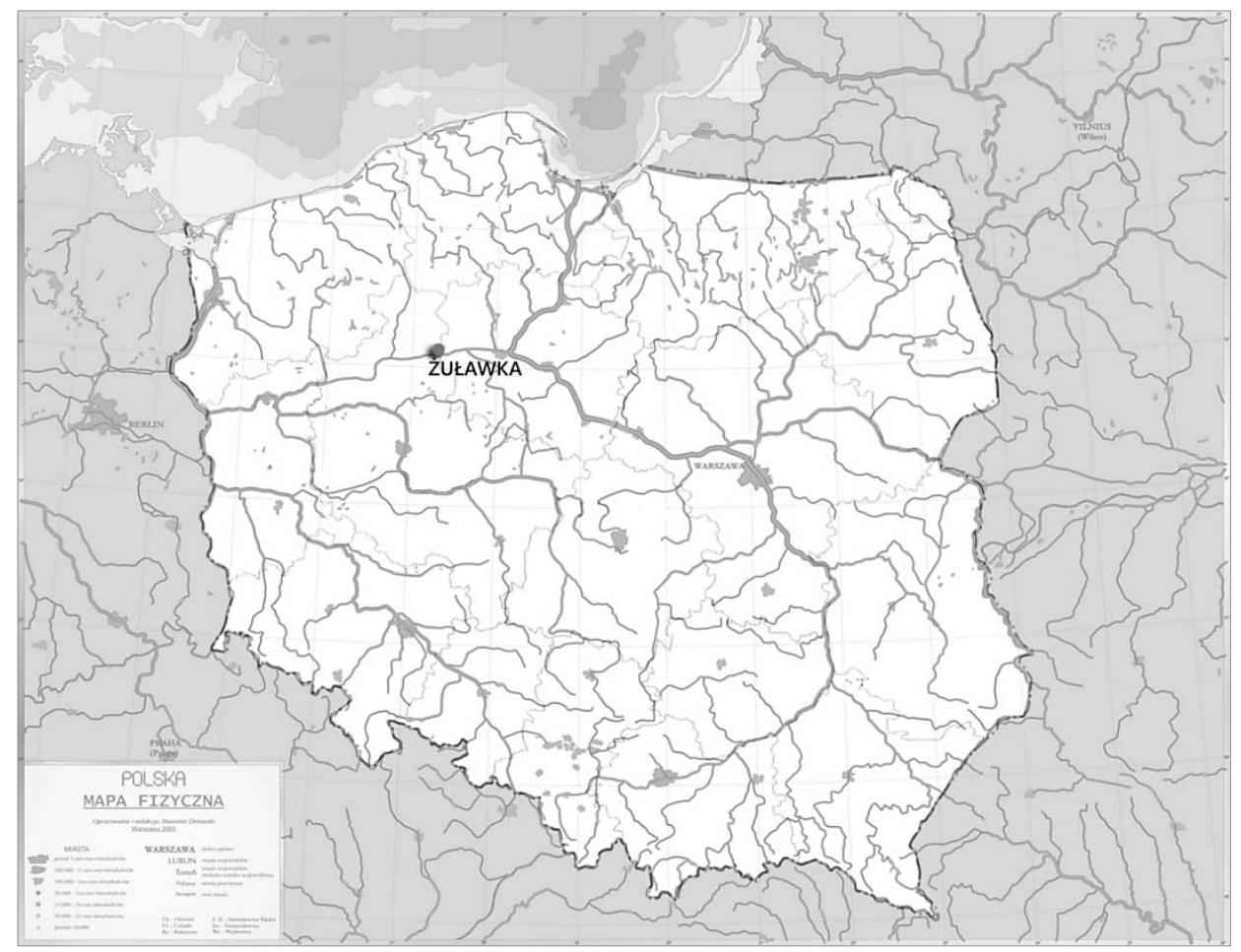

Ryc. 1. Stanowisko Żuławka 13 na mapie Polski

Fig. 1. Żuławka, site 13 in the map of Poland 


\section{MATERIAŁY I METODY}

Badania wykopaliskowe na stanowisku Żuławka 13 odbywały się w trzech sezonach w latach 1996 i 1998-1999 i prowadzone były przez mgr. Piotra Dmochowskiego w ramach projektu „Mezolit północno-wschodniej Wielkopolski”, finansowanego przez Zakład Epoki Kamienia i Brązu ówczesnego Instytutu Prahistorii Uniwersytetu im. Adama Mickiewicza w Poznaniu. W tym okresie wyeksplorowano $71 \mathrm{~m}^{2}$ powierzchni, z której wydobyto 60964 zabytków krzemiennych. Większość z nich, czyli 39490 zaklasyfikowano jako łuski, czyli materiał o małym potencjale poznawczym. Spośród pozostałych artefaktów największą grupę stanowiły produkty debitażu w liczbie 18818 sztuk. Częściowo można zaliczyć do niej również fragmenty retuszowane, w skład których wchodziły wszystkie narzędzia typologiczne oraz wióry i odłupki retuszowane. Wydobyto ich 2389. Najmniejszy, 267-elementowy zbiór stanowią rdzenie. Aplikacji metody składanek podlegało natomiast jedynie ok. 3-4 tysięce zabytków wiązanych z obecnością społeczności kultury świderskiej. Dokładna historia badań i wstępne opracowanie materiału dostępne jest w artykule autora badań wykopaliskowych P. Dmochowskiego (2005).

Materiał dotyczący bezpośrednio tematu artykułu stanowią składanki zawarte w 36 blokach, których autorem jest Wacław Cichocki. Ich powstanie wiązało się z realizacją jego pracy magisterskiej (Cichocki, 2004). W trakcie prac udało się zawrzeć w blokach 373 zabytków krzemiennych, co daje średnią powyżej 10 elementów na blok. Jest to bardzo dobry wynik, porównując go do podobnych stanowisk z zachodniej części Niżu Polskiego (Kaczor, 2015, 2017; Rakoca, 2013, 2015). Do badań nad organizacją przestrzenną obozowiska wykorzystano wszystkie składanki, do analizy technologicznej natomiast tylko te ujęte w 9 najbardziej perspektywicznych blokach, które zawierały jednak 63\% wszystkich poskładanych elementów (Cichocki, 2003; Kaczor, 2017). Te 9 bloków będzie również opisane w rozdziale dotyczącym analizy materiału.

Głównym aparatem analitycznym wykorzystanym w badaniach jest wspomniana już wcześniej metoda składanek. Z całego materiału krzemiennego wyselekcjonowano zabytki wiązane przez autora badań wykopaliskowych z osadnictwem świderskim. Kolejnym etapem przygotowawczym był podział wydzielonego zbioru pod względem surowcowym. Dodatkowo dokonano pogrupowania wg dynamicznej klasyfikacji technologicznej. Ograniczyło to znacznie czas związany z aplikacją metody składanek (Cichocki, 2003; Tomaszewski, 1986).

Podczas dwóch przeprowadzonych badań wykorzystano dwa różne podejścia interpretacyjne. Pierwsze opracowanie skupione było głównie na rozpoznaniu struktur osadniczych oraz relacji między nimi, aspekty technologiczne potraktowano zdawkowo. Wykonane do niej składanki analizowane były przy pomocy planigrafii pionowej i poziomej oraz w mniejszym stopniu łańcucha operacji. Interpretacja dotyczyła wyszukania prawidłowości między rozkładem przestrzennym elementów 
złożonych bloków a ich miejscem w łańcuchu operacji lub klasyfikacją typologiczną. Pozwoliło to na dokładne zdefiniowanie rodzajów skupien, ich wzajemnych relacji oraz wydzielenie miejsc aktywności społeczności kultury świderskiej na tym wielokulturowym stanowisku (Cichocki, 2003).

Inne podejście zaprezentowane zostało podczas drugiego podejścia do interpretacji materiału. Zabytki z Żuławki weszły w skład stanowisk wybranych do realizacji pracy magisterskiej autora artykułu. Badania skupione były tym razem tylko na szeroko rozumianymi aspektami technologicznymi. Bazowano głównie na analizie łańcucha operacji oraz w mniejszym stopniu na cechach niemetrycznych pojedynczych elementów składanek. Do interpretacji wybrano podejście uwzględniające kwestie behawioralne i kognitywne, co umożliwiło kompleksowe rozpoznanie technologii krzemieniarstwa społeczności kultury świderskiej, która zamieszkiwała owe tereny na przełomie plejstocenu i holocenu (Kaczor, 2017).

\section{ANALIZA}

Blok nr 1: ryc. 3 (1)

Na ten blok przypadają cztery duże składanki (8-20 elementów) oraz 12 małych zawierających 2-3 elementy. Na potrzeby pracy opisane zostaną dwie z nich określone jako $1 \mathrm{~A}$ i $1 \mathrm{D}$.

Materiał z tego bloku grupuje się na $8 \mathrm{~m}^{2}$, przy czym centrum o największym zagęszczeniu zajmuje ok. $1 \mathrm{~m}^{2}$. Na planie wykopu znajduje się $\mathrm{w}$ jego centralnej części. Widoczne jest również przesunięcie w kierunku północnego wschodu, co należałoby wiązać $\mathrm{z}$ erozją stokową. Inna partia przesunęła się w stronę humusu, jednak większość odnaleziono w najgłębszych warstwach wykopu. Mogłoby się wydawać, że materiał rozproszył się podczas rdzeniowania, jednak analiza warstw wskazuje na czynniki postdepozycyjne.

Celem rdzeniowania w składance 1A zdaje się być wytworzenie jednego wióra o określonych parametrach. Pierwszym zabiegiem było odbicie zaprawiaków tworzących odłupnie. Następnie uderzeniem czołowym wytworzono piętę. Do wyprowadzenia oczekiwanego wióra posłużono się odbiciami wiórów pobocznych. Kolejnym zabiegiem miało być uformowanie dolnej części przygotowywanego produktu, co zakończyło się jednak głębokim uderzeniem zawiasowym niszczącym pół odłupni. Elementy mają cechy uderzenia miękkim tłukiem.

Składanka 1D przedstawia odbicie serii odłupków, których celem było wyrównanie powierzchni zawierającej głębokie zagłębienie, będące zapewne przeszkodą w obróbce. Przed tą serią odbito kilka małych odłupków zmniejszających masę uchwyconych w składance elementów. Obróbka przebiegała „naokoło” zagłębienia, co wskazuje na zaawansowaną wiedzę wytwórcy, ponieważ uderzenie bezpośrednio mogłoby spowodować powstanie zawiasu. Łańcuch operacji kończy odbicie drobnych odłupków niwelujących krawędź zagłębienia. 
Blok nr 6: ryc. 2 (3)

Blok składa się z czterech składanek. Dwie z nich są dwuelementowe, jedna ośmioelementowa, a największa składa się z 25 elementów. Przedstawiają różne etapy eksploatacji.

Materiał złożony zalegał na powierzchni ok $1,5 \mathrm{~m}^{2} \mathrm{w}$ południowo-zachodnim rogu wykopu na poziomie warstw 7-13. Niezłożony materiał również kumulował się w tej części, jednak jego zagęszczenie było mniejsze. Największemu przemieszczeniu uległ odłupek odnaleziony w humusie. Nie odnaleziono dla tego bloku mikrodebitażu, co skłonić może do stwierdzenia, że rdzeniowanie odbywało się w innym miejscu.

Składanka ośmioelementowa pochodzi ze wstępnego etapu obróbki. Wszystkie elementy posiadają fragmenty powierzchni naturalnej i pokryte są nią w całości, z czego wyczytać można, że bryła była spękana przed jej użyciem. Obróbka uchwycona w składance rozpoczyna się od sekwencji podstawiak-wiór-świeżak, po której następuje odbicie dwóch wiórów. Następnie znacznie obniżono piętę. Po tym odbito trzy wióry formujące trójkątny kształt odłupni.

Największa składanka w tym bloku przedstawia obróbkę właściwą. Praktycznie wszystkie jej elementy to wióry odbijane w różnych sekwencjach, których nie można określić dokładnie przez brak elementów z jednej strony. Można domyślać się, że wióry uchwycone w składance służyły do przygotowania odbicia konkretnych form. Pośrednim dowodem na to może być negatyw wióra liściakowego, wyraźnie przygotowanego przez kilka odbić. Seria ta najbardziej przypomina świderską technologię krzemieniarska znaną ze stanowisk w pobliżu wychodni krzemienia czekoladowego. Wszystkie elementy zawarte w bloku posiadają cechy obróbki miękkim tłukiem.

Blok nr 7: ryc. 3 (2)

Blok składa się z pięciu składanek, dwie są dwuelementowe, dwie trójelementowe, a największa składa się z 21 elementów. Mniejsze składanki przedstawiają kształtowanie zatępca i formowanie odłupni w jednej ze składanek trójelementowych, najprawdopodobniej kształtowanie górnej części zatępca w drugiej składance trójelementowej. W składankach dwuelementowych ciężko określić ich przynależność do któregoś z etapów obróbki, jednak wydaje się, że jedna z nich stanowi element formowania pięty, bądź pierwszych odbić dostosowujących bryłę, a druga $\mathrm{z}$ nich przedstawia formowanie boku, tyłu lub wczesny etap kształtowania odłupni.

Materiał grupował się w południowo-zachodnim narożniku wykopu na powierzchni ok $2 \mathrm{~m}^{2}$. Wyraźnie poza skupieniem znajdował się duży wiór ujęty w składance. Znalazł się tam najprawdopodobniej w wyniku depozycji (użycie, przeniesienie) niż w wyniku obróbki czy procesów postdepozycyjnych. Podobnie jak w przypadku skupienia 6 , tu również nie odnaleziono mikrodebitażu. 
Największa ze składanek tego bloku zawiera w sobie praktycznie wszystkie elementy obróbki. Bryła miała dyskoidalny, spłaszczony kształt, narzucający sposób obróbki. Łańcuch operacji rozpoczyna się od odbicia masywnego podstawiaka na jednej z krawędzi. Następnie ukształtowano tył rdzenia i rozpoczęto tworzenie drugiej pięty. Kolejnym zabiegiem było ostateczne uformowanie pięty głównej. Po tym ukształtowano bok rdzenia przez odbicie dwóch płaskich odłupów o dużej powierzchni. Następnie odbiciem czołowym wykonano piętę dolną. Na tym zakończyły się zabiegi wstępne, a rozpoczęło rdzeniowanie. Najprawdopodobniej pierwszym etapem było wykonanie i odbicie zatępca, co jest zabiegiem standardowym. Następnie przystąpiono do odbijania wiórów naprzemiennie z obu pięt, z zachowaniem ról - pierwsza pięta była wiodąca, druga natomiast pomocnicza. Sekwencję kończą dwa odbicia zawiasowe z pięty głównej, których mimo dużej masy rdzenia nie starano się naprawić. Być może powodem tego był kształt dolnej jego części, który uniemożliwiał wykorzystanie dolnej pięty do naprawy. Widoczne jest rozdzielenie w cechach technicznych, początkowe etapy zawierają cechy twardego tłuka, a rdzeniowanie cechy tłuka miękkiego.

Blok nr 8: ryc. 2 (4)

Blok zawiera sześć składanek, w tym dwie o dużym potencjale interpretacyjnym. Jedna $\mathrm{z}$ nich złożona jest $\mathrm{z}$ zatępca, dwóch podtępców i trzech elementów kształtowania zatępca. Zatępiec wytworzono przez dwa większe odbicia po obu stronach oraz serię mniejszych dokładnych wiórków i odłupków. Wszystkie zabiegi wykonane były przy użyciu tłuka miękkiego

Materiał z tego bloku na planie poziomym rysują się w południowo-zachodnim narożniku wykopu. Koncentrują się na powierzchni $1,5 \mathrm{~m}^{2}$. Podobnie jest z zabytkami niezłożonymi, które powinny należeć do tego bloku. Wyjątek stanowi kilka zabytków rozmieszczonych wzdłuż zachodniej granicy wykopu oraz dwa na wschód od nich.

Składanka o największym potencjale poznawczym w tym bloku zawiera rdzeń dwupiętowy, kilka wiórków i odłupków z rdzeniowania oraz element rdzenia, który odpadł w wyniku pęknięcia bryły. Łańcuch operacji rozpoczyna się obróbką rdzenia dwupiętowego, zawierającego jeszcze część, która odpadła przez spękanie. Do pęknięcia doszło najprawdopodobniej w wyniku odbicia wióra z pięty, która pozostała w rdzeniu użytkowanym $w$ dalszej części. Po tym incydencie zaprzestano obróbki mniejszego fragmentu i z powierzchni spęku wytworzono drugą piętę. Rdzeniowanie nadal odbywało się na tej samej płaszczyźnie. Sama odłupnia była bardzo szeroka, eksploatowano praktycznie $180^{\circ}$, zapewne wykorzystując tak dużą szerokość do wysuwania punktów uderzenia i formowania trójkątnych w przekroju wiórów. Wszystkie złożone elementy mają cechy uderzenia miękkim tłukiem, choć na negatywach widoczne jest kilka uderzeń tłukiem twardym, co widoczne jest również na niezłożonych elementach zakwalifikowanym do bloku. 
Blok nr 9: ryc. 2 (2)

Blok złożony jest z artefaktów wykonanych z krzemienia pomorskiego (jaskółczy chlebek). Zabytki związane z tym blokiem zalegały w południowo-zachodniej części wykopu na powierzchni $1,5 \mathrm{~m}^{2}$. Poza koncentrację wychodziły jedynie dwa z nich, które musiały się przemieścić już po depozycji, najprawdopodobniej przez erozję stokową.

Składanka zawiera prawie wszystkie elementy eksploatacji rdzenia. Obróbka rozpoczęła się od odbicia podstawiaka z jednego ze szczytów konkrecji. Następnie odbito kilka odłupów korowych, a po nich kilku korowych wiórków. Kolejnym etapem było najprawdopodobniej wytworzenie pierwszego zatępca na węższym boku, jednak koncepcja obróbki na tym boku się nie powiodła i rdzeniowanie przeniesiono na bok szerszy. Formowanie pierwszego zatępiska nie zostało uchwycone w składance, jest jednak widoczne na negatywach. Drugi zatępiec natomiast jest już dobrze udokumentowany. Stworzono go na krawędzi między węższym i szerszym bokiem. Dolną jego część ukształtowano dwoma relatywnie masywnymi odłupkami. Rdzeniowanie odbywało się na obu bokach, pod koniec zajęło nawet drugi węższy bok, pozostawiając jedynie tylną płaszczyznę bez obróbki. Eksploatację rdzenia zakończyło odbicie wióra przeniesionego, który zmniejszył długość rdzenia blisko dwukrotnie (ok. 2,2 cm odłupnia i 3,5 tył). Rdzeń nie został odnaleziony, jednak trudno przypuszczać, aby społeczności świderskie próbowały dalszej obróbki tak małego rdzenia. Wszystkie elementy posiadają cechy uderzenia miękkim tłukiem kamiennym, które stawały się coraz delikatniejsze w miarę trwania eksploatacji rdzenia.

Blok nr 10: ryc. 4 (1)

Blok składa się z trzech składanek. Pierwsza z nich to 11 elementów stanowiących wytworzenie zatępiska oraz jego egzekucję i odbicia podtępcowe. Druga jest serią trzech odbić korekcyjnych, mających wyrównać najprawdopodobniej bok konkrecji. Trzecia to rdzeń szczątkowy i dwie odłupnie.

Materiał skupiony był w południowo-zachodniej części wykopu na przestrzeni $1,5 \mathrm{~m}^{2}$. Poza skupieniem znajdował się rdzeń, który został odnaleziony w humusie ok. metr od skupienia. Poza nim oddalony był jeszcze zatępiec, znajdujący się ok. $3 \mathrm{~m}$ na północny wschód.

Łańcuch operacji w największej składance rozpoczyna się od uderzeń formujących konkrecję i odbicie podstawiaka. Drugim etapem było wytworzenie zatępiska, w tym uchwycone w składance odbicie odłupków w dolnej części rdzenia. Następnie doszło do egzekucji zatępca. Po tym przystąpiono do wytworzenia drugiej pięty oraz świeżenia pierwszej. Rdzeniowanie przebiegało standardowo z podziałem pięt na role, górna była piętą główną, dolna pomocniczą. Układ ten utrzymywał się podczas całości rdzeniowania. Zmieniała się jednak wysokość pięt. Przed końcową eksploatacją doszło do co najmniej jednego odnawiania na obu piętach. Obróbka zakończyła się przez ubytek w masie rdzenia na jednej z pięt, co uniemożliwiało 
dalsze skuteczne wykorzystanie koncepcji dwupiętowej. Techniki uderzenia wydają się przenikać. Dominują cechy miękkie, jednak nawet w trakcie rdzeniowania pojawiają się cechy uderzenia twardym tłukiem.

\section{Blok nr 14}

Blok składa się z trzech składanek. Pierwszą stanowi rdzeń szczątkowy dwupiętowy, świeżak w postaci wiórka, wiórek z zaprawy rdzenia oraz wiór zawiasowy. Druga składanka składa się z dwóch wiórków, w tym jednego zawiasowego, trzecia natomiast zawiera dwa elementy wióra.

Materiał był bardzo rozproszony i zajmował ok. $8 \mathrm{~m}^{2}$ na północny zachód od centrum wykopu. Poszczególne składanki nie łączą się w skupienia, jednak znajdowały się na podobnej głębokości (9-11 warstwa mechaniczna).

Łańcuch operacji w tym bloku można opisać głównie na podstawie rdzenia i elementów do niego dołączonych. Rdzeń ten miał dwie pięty, jedna o kącie rdzeniowania ostrym, lecz zbliżonym do prostego, druga o kącie zdecydowanie ostrym (poniżej $45^{\circ}$ ). Pierwsza z pięt była zdecydowanie piętą główną, druga pozwalała na uzyskiwanie krótkich wiórków korekcyjnych lub kształtujących część dalszą pozyskiwanego półsurowca wiórowego. Zaprawiony został również tył rdzenia, najprawdopodobniej w celu lepszej kontroli boków i odłupni. Wszystkie elementy zawarte w składance, jak i negatywy wskazują na użycie tłuka miękkiego.

Blok nr 15: ryc. 2 (1)

Blok składa się z dwóch składanek, jednej siedmioelementowej, zawierającej pęknięty rdzeń z zaprawą boku w postaci wióra i trzech odłupków. Druga składanka to dwa rylczaki.

Materiał tworzy jednolite skupienie na południowy zachód od centrum wykopu. Zajmuje ok $1 \mathrm{~m}^{2}$ powierzchni. Ich dyspersja wertykalna jest jednak bardziej zróżnicowana, występowały od 7 do 12 warstwy mechanicznej. Poza skupieniem znajdowały się dwa rylczaki (północna krawędź wykopu), które znalazły się tam najprawdopodobniej w trakcie wytwarzania narzędzia (rylca).

Łańcuch operacji rozpoczyna się od zaprawy tyłu i boków rdzenia. Kolejnym zabiegiem było wytworzenie pierwszej pięty, po czym uformowano odłupnię, co zakończyło się pęknięciem rdzenia i w konsekwencji korzystnym zwężeniem jednego z boków. Z mniejszej części rozbitej konkrecji odbito jeden wiór, większa natomiast służyła do dalszej obróbki. Rozpoczęto od stworzenia dwóch pięt i korekcji boku odbiciem odłupka od tyłu rdzenia. Rdzeniowanie przebiegało na zasadzie jednego uderzenia z pięty małej i dwóch z pięty dużej. Pierwsza z nich służyła do egzekucji oczekiwanego półsurowca, druga natomiast do korekcji i kształtowania dolnej części rdzenia. Cechy technologiczne zmieniały się wraz z rozwojem eksploatacji, od twardych w początkach obróbki do miękkich podczas rdzeniowania. 
Blok nr 20: ryc. 4 (2)

Blok składa się z dwóch składanek, jednej dwuelementowej, która zawiera dwa wióry bite z przeciwnych stron oraz druga - ośmioelementowa, która przedstawia początkowy etap obróbki do odbicia zatępca i jednego wióra.

Materiał nie tworzył zwartego skupienia, zajmował powierzchnię ok. $5 \mathrm{~m}^{2}$ na północny zachód od centrum wykopu. W planigrafii pionowej również zauważalne jest duże rozproszenie. Zabytki występowały od warstwy mechanicznej 4 do 13 . Dzięki liniom składanek można zaobserwować erozję stokową.

Łańcuch operacji rozpoczyna się od czterech odłupków formujących trójkątną w przekroju grań i dwóch wiórów zwężających potencjalny zatępiec, który został wyegzekwowany następnie. Po tym zabiegu w składance uchwycono tylko dwa wióry, które wskazują na odnawianie pięty w trakcie obróbki. Obróbka wydaje się być prowadzona z jednej pięty, drugą natomiast, którą tworzyła naturalna płaszczyzna, wykorzystywano doraźnie do naprawy błędów, bądź korekcji wybitnie niekorzystnego układu odłupni. Być może nie była ona nawet traktowana jako odłupnia, a jako platforma zbliżona zadaniem do boków rdzenia. Również w przypadku tej składanki widoczne jest zróżnicowanie cech technicznych, na twardsze uderzenia w początkowej obróbce i miękkie w trakcie rdzeniowania.

Nieznany jest pierwotny kształt bryły, jednak widoczna w składance jest część wybrana pod przyszłą odłupnię. Tworzy ona pozorny ostrosłup z wierzchołkiem (a raczej krótką granią) w dolnej części przyszłego rdzenia. Figura ta została zniwelowana przez odbicie trzech odłupków, co doprowadziło do wytworzenia odłupni o regularnym trójkątnym przekroju.

Pozostałe bloki mają za mały potencjał badawczy i z powodu ograniczenia objętości artykułu nie zostały objęte opisem. Ich analiza znajduje się w maszynopisie pracy magisterskiej W. Cichockiego (2003). W interpretacji jednak materiały te zostaną ujęte ze względu na możliwość powstania pewnego świadomego przekłamania, szczególnie w analizie przestrzennej.

\section{INTERPRETACJA}

\section{Relacje przestrzenne}

W wyniku badań na stanowisku Żuławka 13 wyróżniono trzy pracownie oraz usypisko (śmietnisko). Pierwsza pracownia, o powierzchni ok. $8 \mathrm{~m}^{2}$, najbardziej obfita w zabytki, znajduje się na południe od centrum wykopu. Jest to miejsce rdzeniowania siedmiu bloków (1, 2, 3, 4, 5, 21, 34). Główna część skupienia znajduje się od 8 do 16 warstwy mechanicznej. Część materiału została wyniesiona nawet do humusu, a część spłynęła na północ i północny wschód, wraz ze zwrotem spadku stoku. Znaleziono w niej wiele typów narzędzi oraz mikrodebitaż, co wskazuje na jej pracowniany charakter. 
Pracownia druga była zlokalizowana na północny zachód od centrum wykopu i zajmowała ok $4 \mathrm{~m}^{2}$ powierzchni. Miało tu miejsce rdzeniowanie bloków 14, 15, 17 i 20. Materiał z tych bloków był jednak mocno rozrzucony po stanowisku. Najdalszy element znajdował się $8 \mathrm{~m}$ od skupienia. Występowanie narzędziowych form typologicznych i mikrodebitażu oraz rdzeni wskazuje na jego pracowniany charakter.

Pracownia trzecia była zlokalizowana przy zachodniej krawędzi wykopu i obejmowała ok. 1,5 m² powierzchni. W jej skład wchodził materiał z bloków nr 12 i 18 . Odnaleziono tam jeszcze pojedyncze elementy z bloków 13, 19, 23 i 26. Skupienie to podlegało silnym procesom postdepozycyjnym.

Usypisko (śmietnisko) znajdowało się w południowo-zachodnim narożniku wykopu. Jego trzon stanowiły elementy bloków $6,7,8,9,10$ i 11 . Znalazły się tu również części bloków 13, 15, 16, 18, 23, 24 i 26. Znajdujący się tu materiał ma cechy bardzo charakterystyczne dla celowej depozycji odpadów produkcyjnych. Na małej powierzchni $\left(1 \mathrm{~m}^{2}\right)$ odnaleziono wiele rdzeni i produkty debitażu. Brakuje natomiast narzędzi i mikrodebitażu, jak i półsurowca przeznaczonego na wykonanie narzędzi. Brak jest w jego obrębie domieszki materiałów o innej atrybucji kulturowej. Skupienie to przyniosło również najliczniejsze składanki. Całe skupienie nie uległo dużym przekształceniom postdepozycyjnym. W usypisku tym odkryto również ok. 200 fragmentów szczątków ptasich.

Dzięki planigrafii pionowej i poziomej możliwe było uchwycenie zależności między obszarami aktywności społeczności świderskich na stanowisku. Najbardziej wyraźne jest połączenie pracowni trzeciej i usypiska. Wielokrotne połączenia w składankach dowodzą, że były to obiekty jednoczasowe. Dowodem są bloki 13, 18, 23 i 26. Pozostałe pracownie pozornie wydają się związane ze śmietniskiem (w planigrafii poziomej), jednak przy dokładnej analizie ich położenia zauważalny jest brak ich korelacji w planigrafii pionowej. Zazwyczaj zabytki z bloków obrabianych w pierwszej lub drugiej pracowni znajdują się powyżej usypiska. Prawdopodobnie zostały tam przeniesione przez zwierzęta ryjące, jednak wątpliwe jest, aby wybierały one tylko zabytki pochodzące z tych skupień. Prawdopodobieństwo takiego zdarzenia jest na tyle małe, że można wykluczyć korelację ze śmietniskiem pracowni pierwszej i drugiej.

\section{Technologia}

Materiał ze stanowiska Żuławka 13 w dużym stopniu przypomina krzemieniarstwo świderskie, znane ze stanowisk z dużym udziałem krzemienia czekoladowego. Bez wątpliwości można sklasyfikować je jako świderskie wg dotychczas wypracowanych standardów technologicznych. Występują tu duże formy dwupiętowe, w rdzeniowaniu łatwo dostrzec długie serie wiórowe, głównie w modelu preferencyjnym.

Rdzenie jednopiętowe są wśród dużych składanek rzadkością. Jeden z nich jest formą szczątkową, która koncepcyjnie mogła być dwupiętowa, a drugi z nich (a raczej drugi blok) jest wykonany na krzemieniu pomorskim (tzw. jaskółczy chle- 
bek). Do sposobu obróbki jednopiętowej nawiązuje też jeden z rdzeni dwupiętowych (blok 8), jednak wyraźne jest wykorzystanie obu pięt. Model obróbki nie przypomina wykorzystania różnych rodzajów rdzeni do pozyskiwania różnego półsurowca. Składanka z jaskółczego chlebka prezentuje bardzo wyrafinowane krzemieniarstwo, które prowadziło zapewne do wytworzenia jednego lub dwóch wiórów o oczekiwanej formie. Można też zauważyć na niej przygotowanie prowizorycznej platformy na dole rdzenia, która mogła w razie błędu stać się drugą piętą.

Rdzenie dwupiętowe wspólnoodłupniowe eksploatowane były w sposób charakterystyczny dla obróbki świderskiej. Dwóm piętom nadawano najczęściej różne funkcje. Widoczne było to w składankach oraz negatywach. Również ich kształt i kąt rdzeniowania wskazywał na ich przeznaczenie. W ten sposób pięty o większej powierzchni i kącie rdzeniowania lekko ostrym lub zbliżonym do prostego służyły do odbijania wiórów preferencyjnych i prowadzenia głównych zabiegów formujących, a podczas realizowania modelu seryjnego służyły do egzekucji pożądanego półsurowca. Pięty pomocnicze natomiast były najczęściej mniejsze, czasami formowane doraźnie w trakcie obróbki, posiadały bardzo ostry kąt rdzeniowania i służyły do formowania części dystalnej wiórów podczas rdzeniowania preferencyjnego oraz do korekcji kształtu odłupni przy realizacji modelu seryjnego.

Formowanie pięt i odłupni, tak jak nadawanie kształtu rdzeniom, również podlegało podobnym zasadom jak w „czekoladowej” wersji krzemieniarstwa świderskiego (Fiedorczuk, 1992). Cechowała je duża nonszalancja i duże straty materiału. Przykładem jest np. niwelowanie zagłębienia (blok 1), które doprowadziło do zmniejszenia się masy, jednak pozwoliło na wyeliminowanie niedogodności. Pięty były często tworzone przez jedno odbicie i tak funkcjonowały przez całą eksploatację. Zdarzało się również doraźne świeżenie, bądź odnawianie (zazwyczaj bardzo radykalne, obniżające platformę o ok. $5 \mathrm{~mm}$ ). Odłupnie powstawały zazwyczaj przez odbicia dużych odłupków, które tworzyły trójkątną w przekroju formę, którą następnie zatępiano i rozpoczynano obróbkę od zatępca.

W rdzeniowaniu kierowano się dwoma modelami - preferencyjnym i seryjnym (Migal, 2007). Częściej stosowany był ten pierwszy, co tłumaczyć można docelowym pozyskiwaniem półsurowca liściakowego i wykorzystywaniem odpadów produkcyjnych do wytworzenia innych narzędzi. Zdarzało się również odbijanie w sekwencjach dwa z dołu (formujące część dystalną) i jeden z góry (przygotowany przez mniejsze odbicia i wysunięcie punktu pod uderzenie). Było to stosowane jednak przy bardzo wąskiej odłupni. Na jednej ze składanek można zauważyć próby pozyskania trójkątnych w przekroju, masywnych i niezbyt długich wiórów. Dokonywano tego przez obróbkę trzech boków oraz stopniowe wysuwanie i przygotowywanie ich krawędzi do odbicia konkretnego wióra.

Czytanie bryły w przypadku stanowiska Żuławka 13 ograniczone było zazwyczaj do potencjalnego wykorzystania węższego boku do prowadzenia rdzeniowania. Nie przykładano natomiast zapewne dużej uwagi do początkowej formy, przygotowując raczej schemat obróbki, który nada odpowiedni kształt rdzeniowi. 


\section{WNIOSKI KOŃCOWE}

Analiza przestrzenna dowiodła, że stanowisko Żuławka 13 zasiedlane było kilkukrotnie. Pierwsze ślady związane były z pracownią trzecią oraz usypiskiem. Linie połączeń w składanki wskazały wyraźnie na ich jednoczasowość. Drugim epizodem jest funkcjonowanie pracowni pierwszej, trzecim natomiast pracowni drugiej. Brak połączeń między nimi $\mathrm{w}$ trójwymiarowej planigrafii obalił raczej możliwość ich współwystępowania z innymi obiektami na stanowisku. Zagadką jest wciąż nieodkryte dotąd ok. 90\% stanowiska, które dostarczyłoby kompletnych danych o relacjach między przestrzeniami aktywności społeczności świderskich w tym miejscu. Autor opracowania przestrzennego (W. Cichocki) przywołuje również zdanie J. Fiedorczuka ,[...] model społeczności późnopaleolitycznych Niżu Zachodnioeuropejskiego [...] nie sprawdza się w przypadku kompleksu mazowszańskiego na Niżu Polskim, a to z powodu niemal zupełnego braku stanowisk, którym można przypisać rolę stałych obozowisk". Również nie można wiązać go z modelami społeczności wędrownych łowców proponowanymi przez L. Binforda (Andouze, 1987).

Technologicznie materiały świderskie ze stanowiska Żuławka 13 zbliżony jest w dużym stopniu do tych znanych z centralnej części ekumeny tej kultury. Cechuje go zastosowanie modelu obróbki rdzenia dwupiętowego, w dużej mierze preferencyjnego. Łańcuch operacji również podobny jest do tych znanych m.in. z kompleksu Rydno. Rozpoczyna się zaawansowaną obróbką wstępną, w trakcie której nadaje się kształt rdzeniowi. Kolejnym etapem jest przystosowanie odłupni do debitażu i ostateczne uformowanie pięt. Samo rdzeniowanie odbywa się w sposób z góry zaplanowany. Widoczne jest to w prowadzeniu odłupni (największa wypukłość jest na każdym etapie w podobnym miejscu). W przypadku wystąpienia błędów nie widać zauważalnego na większości stanowisk z dorzecza Warty oszczędzania materiału, a raczej typową dla społeczności świderskich rozrzutność (Kaczor, 2017). Składanki z Żuławki pokazują, że społeczności tam zamieszkujące odbiegały zaawansowaniem technologicznym od podobnych im z grupy surowcowej IV wg Szymczaka, która miałaby być związana z obróbką krzemienia „wielkopolskiego kredowego" (Szymczak, 2000). Rozbieżność taka spowodowana została być może przez występowanie w regionie dużych brył krzemienia o dostatecznej dla realizacji koncepcji świderskiej jakości (Kaczor, 2017).

\section{PODZIĘKOWANIA}

W związku z niedogodnościami związanymi z realizacją tego artykułu chciałbym serdecznie podziękować kilku osobom, bez których by się nie ukazał. Profesorowi Arkadiuszowi Marciniakowi za wzorowe prowadzenie mojej pracy magisterskiej, której częścią było opracowanie stanowiska Żuławka 13, liczne porady 
w trakcie prac nad nią i poświęcenie związane z jej obroną. Dr Katarzynie Pyżewicz za nieocenioną merytoryczną pomoc przy analizie i interpretacji zbioru. Dr. Witoldowi Grużdziowi za celne komentarze dotyczące pracy. Piotrowi Dmochowskiemu za wyrażenie zgody na ponowne opracowanie składanek. Wacławowi Cichockiemu, którego dorobek w tym artykule wykorzystałem, za zadanie sobie trudu złożenia stanowiska i jego analizę przestrzenną. W końcu Patrycji Rutkowskiej za dokumentację i opracowanie graficzne powstałych składanek.

\section{BIBLIOGRAFIA}

Andouze F.

1987 Des modeles et des faits. Les modeles de A. Leroi-Gourhan et de L. Binford confrontés aux résultats récents. Bulletin de la Societé Préhistorique Francaise, 84(10-12), s. 343-352.

Cichocki W.

2003 Relacje przestrzenne między obszarami aktywności osadniczej w schyłkowym paleolicie na stanowisku Żuławka nr 13 [praca magisterska, Instytut Prahistorii UAM, Poznań].

Dmochowski P.

2005 Dotychczasowe wyniki badań wykopaliskowych wielofazowego obozowiska z epoki kamienia w Żuławce, stan. 13, woj. wielkopolskie. Wielkopolskie Sprawozdania Archeologiczne, 7, s. 127-151.

Dziewanowski M.

2006 Flint assemblage Dręstwo 37. A preliminary analysis of predetermined Swiderian debitage. W: A. Wiśniewski, T. Płonka, J. M. Burdukiewicz (red.), The Stone: Technique and Technology (s. 149-166). Wrocław: Uniwersytet Wrocławski, Instytut Archeologii, SKAM Stowarzyszenie Krzemieniarskie.

Fiedorczuk J.

1992 Późnopaleolityczne zespoły krzemienne ze stanowiska Rydno IV 57 w świetle metody składanek. Przegląd Archeologiczny, 39, s. 13-65.

Fiedorczuk J.

2006 Final Paleolithic Camp Organization as a Seen from the Perspective of Lithic Artifacts Refitting. Warszawa: Instytut Archeologii i Etnologii PAN.

Fiedorczuk J.

2014 Masovian Camp Organization in Cut I as Seen From the Perspective of Lithic Artifacts Refitting. W: R. Schild (red.), Całowanie. A Final Paleolithic and Early Mesolithic Site on an Island in the Ancient Vistula Channel (s. 291-333). Warszawa: Instytut Archeologii i Etnologii PAN.

Grużdź W., Pyżewicz K., Migal W., Przeździecki M.

2012 Multi-aspect analysis of flint material from Suchodółka, site 3, the Świętokrzyskie Voivodeship. Światowit, 9(50), s. 245-258.

Kaczor M.

2015 Analiza schytkowopaleolitycznych materiałów krzemiennych ze stanowiska Lubrza 10, woj. lubuskie [praca licencjacka, Instytut Prahistorii UAM, Poznań].

Kaczor M.

2017 Technologia krzemieniarstwa społeczności młodszego dryasu $w$ dorzeczu Warty $w$ świetle metody składanek [praca magisterska, Instytut Archeologii UAM, Poznań]. 
Migal W.

2007 About preferential points in Final Paleolithic. W: M. Kobusiewicz, J. Kabaciński (red.), Studies in the Final Paleolithic Settlement of Great European Plain (s. 185-200). Poznań: Instytut Archeologii i Etnologii PAN.

Przeździecki M.

2014 Krzemieniarstwo schytkowopaleolitycznej kultury wołkuszańskiej w świetle analizy materiałów ze stanowiska 3 w Wotkuszu, gm. Lipsk n/Biebrza, pow. augustowski, woj. podlaskie. Warszawa: Instytut Archeologii UW.

Rakoca A.

2013 Schytkowopaleolityczne $i$ wczesnomezolityczne materiaty krzemienne ze stanowiska Kijewo 6, woj. wielkopolskie. Próba szczegótowej interpretacji chronologicznej na podstawie technologii materiałów krzemiennych ze stanowiska wielokulturowego [praca licencjacka, Instytut Prahistorii UAM, Poznań].

Rakoca A.

2015 Nakopalniana pracownia krzemieniarska ze stanowiska Ktodawa 3, woj. lubuskie. Wydobywanie, selekcja, obróbka i dystrybucja narzutowego surowca krzemiennego [praca magisterska, Instytut Prahistorii UAM, Poznań].

Szymczak K.

2000 Late Glacial in Poland - Culture Differentiation. W: P. Bodu, M. Christensen and B. Valentin (red.), L'Europe centrale et septentrionale au Tardiglaciaire: confrontation des modèles régionaux de peuplement: actes de la Table-ronde international de Nemours, 14, 15, 16 mai 1997 (Nemours, 1997) (T. 7, s. 273-286). Nemours, APRAIF (Mémoires du Musée de Préhistoire d'Ile-de-France).

Tomaszewski J.

1986 Metoda składanek wytworów kamiennych i jej walory poznawcze. Archeologia Polski, 31(2), s. 237-277.

\title{
THE RESULTS OF APPLICATION OF REFITTING METHOD TO THE FLINT MATERIALS FROM ŻUŁAWKA, SITE 13, COM. WYRZYSK, COUNTY PIEA
}

\author{
S u m m a r y
}

The refitting method has been frequently used for the study of the Świderian culture materials. It was also the case with Żuławka, site 13, located upon the Noteć river. On the basis of artefacts collected during excavations conducted in years 1996 and 1998-1999, in 2003 the number of 36 refitted blocks were obtained. At first (in 2003), they were analysed in terms of spatial relations between areas of activities, which was a popular approach towards interpretation at the time. As a result, three workshops and one pile were recognised. With the lines of refitted elements it was observed that two areas of human activity were related, namely the third workshop and the pile. The other two concentrations appeared to be unrelated neither to each other, nor to the other area 
of the trench. However, such a small area of the site has been explored that there are still prospects for further discoveries. In 2017 the materials were reinterpreted, this time in terms of technological analysis. As a result, a technological method was recognised applied by the knappers occupying the area of Żuławka, 13 site. The most frequent was a preferential model of opposite platform cores. The most significant protrusion in this case was located in approximately $1 / 3$ of the length, which allowed for defining also functions of platforms. Forming of cores was characterised by a significant waste of material, which might suggest close connotations with Świderian models applied to a raw material known as chocolate flint. In case of the site, the process observed was meant more to shape cores than to explore an original form of a nodule.

Translated by Lucyna Leśniak 


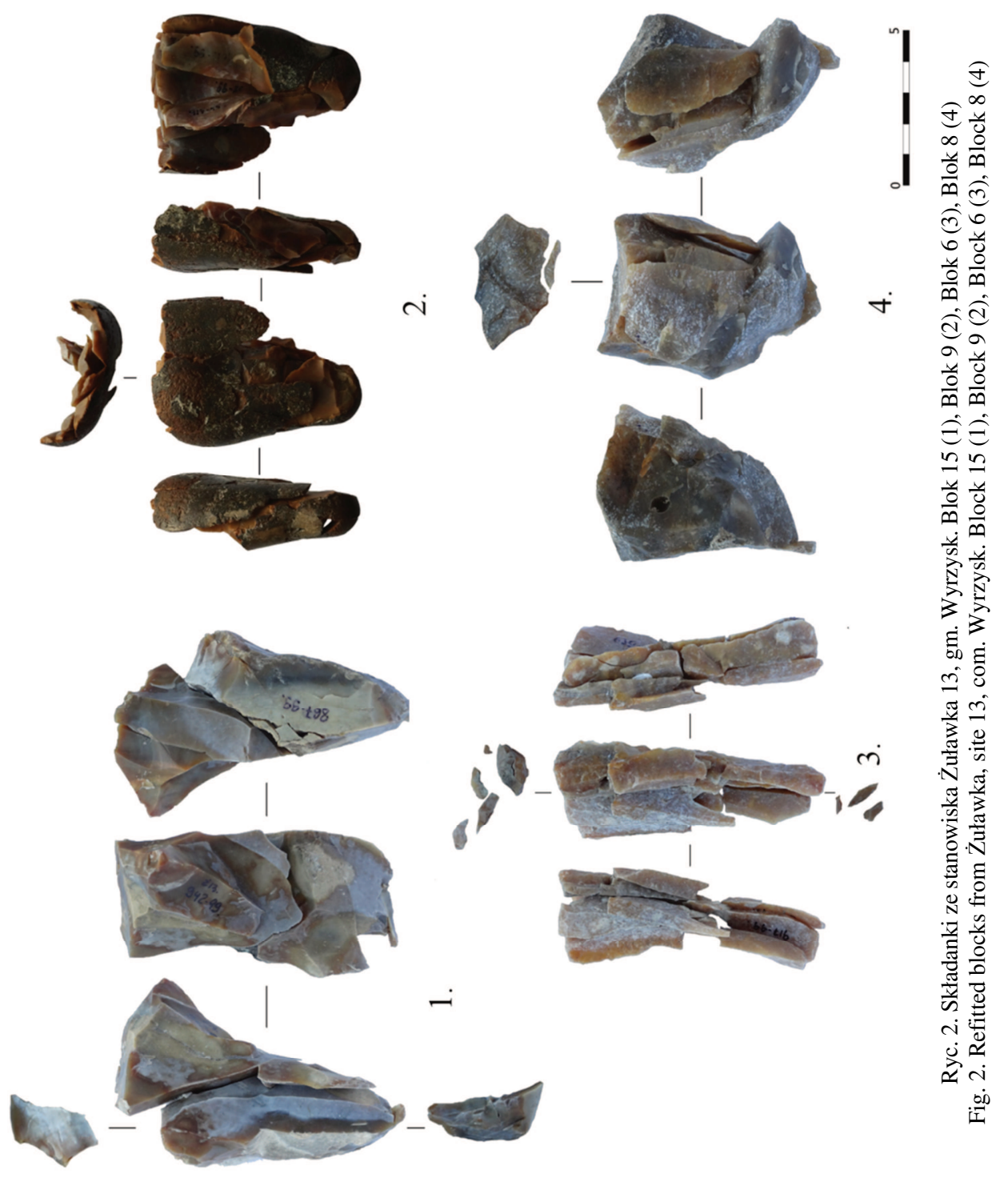




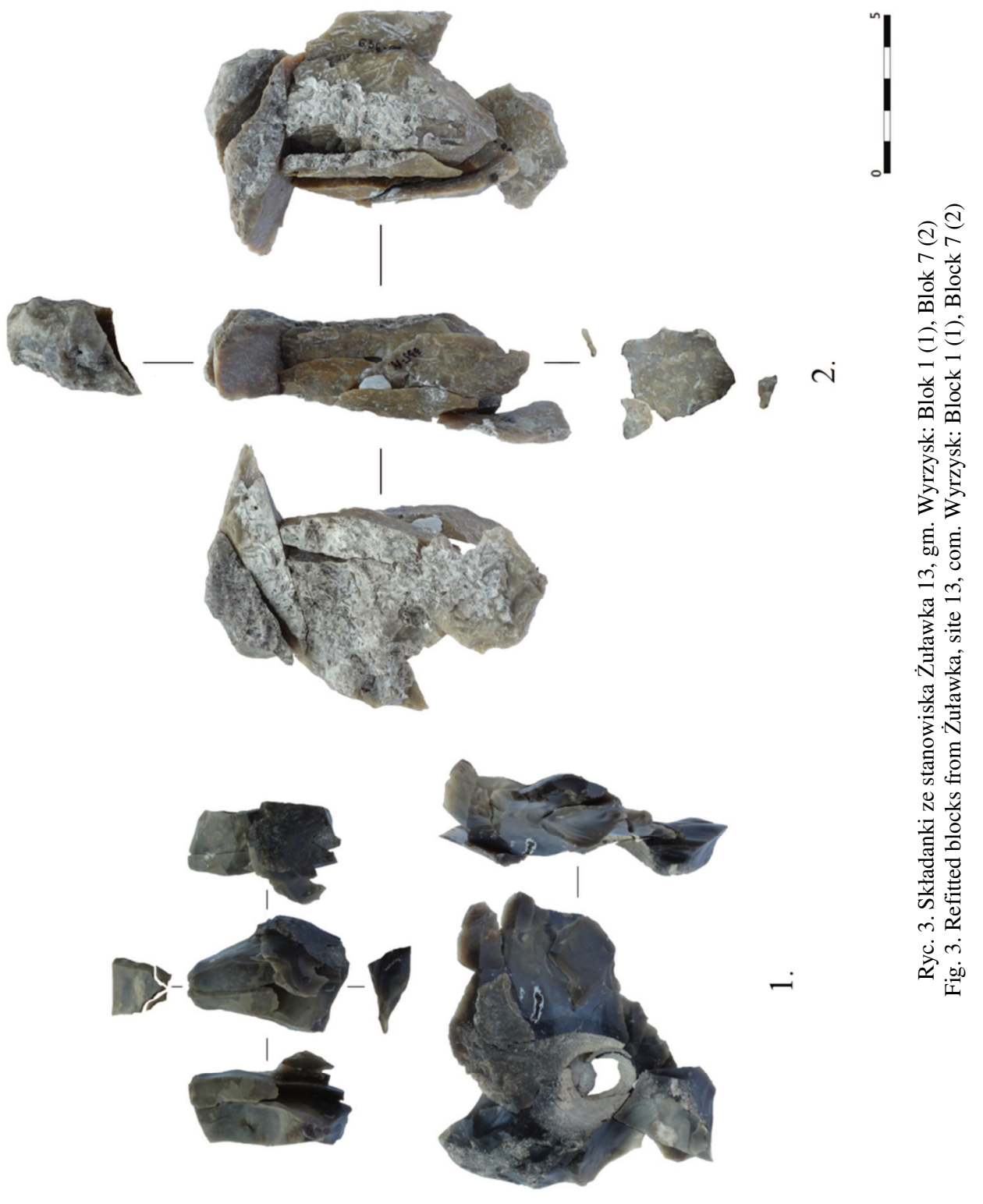




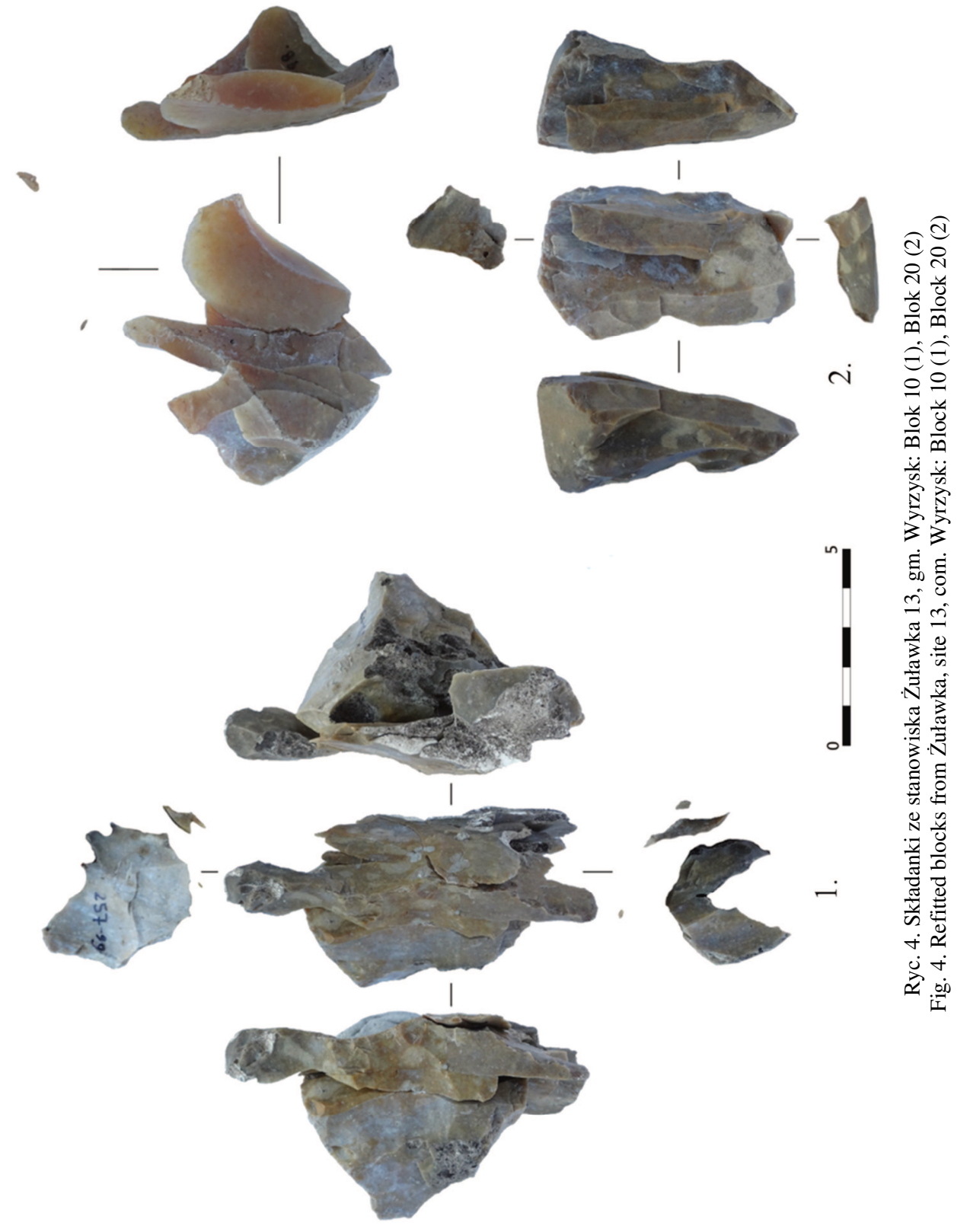




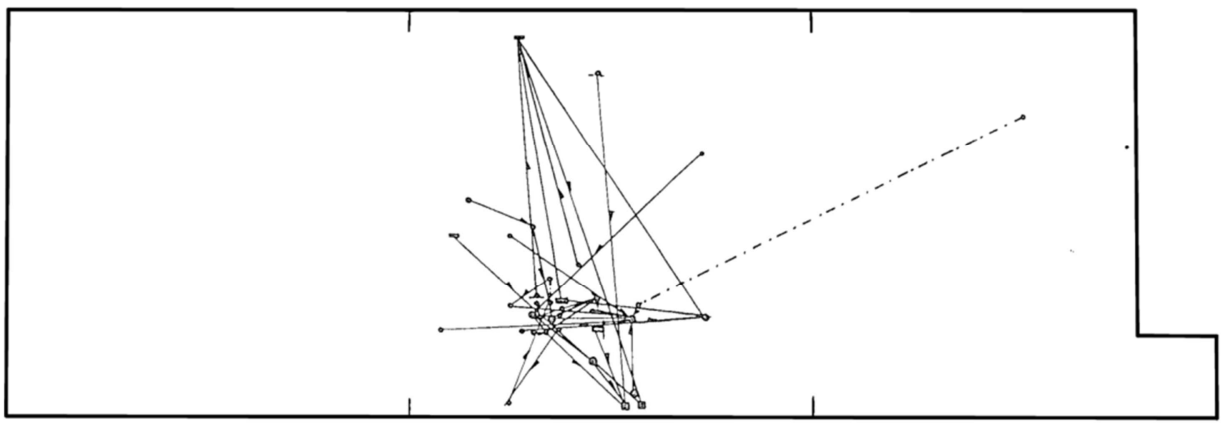

1.

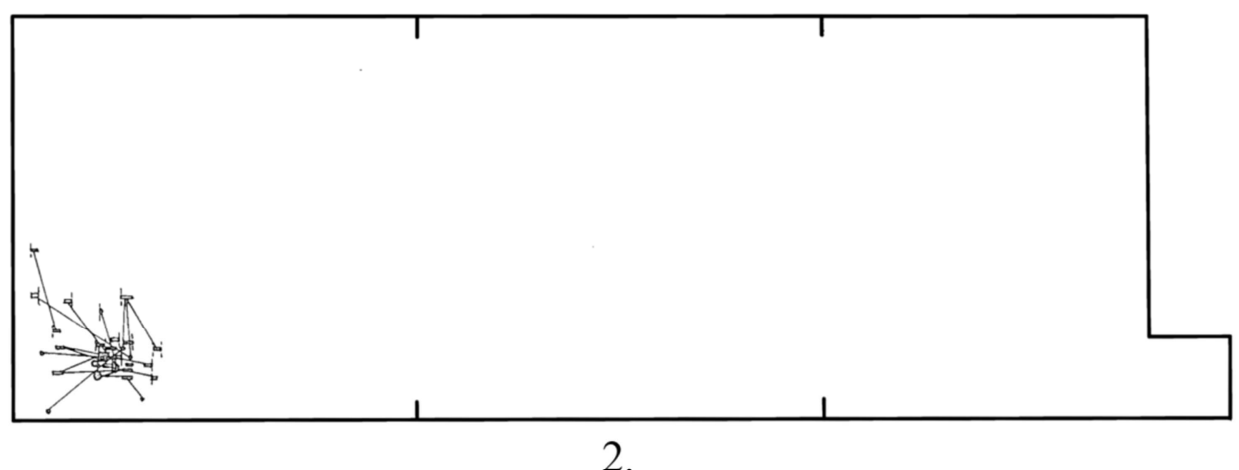

2.

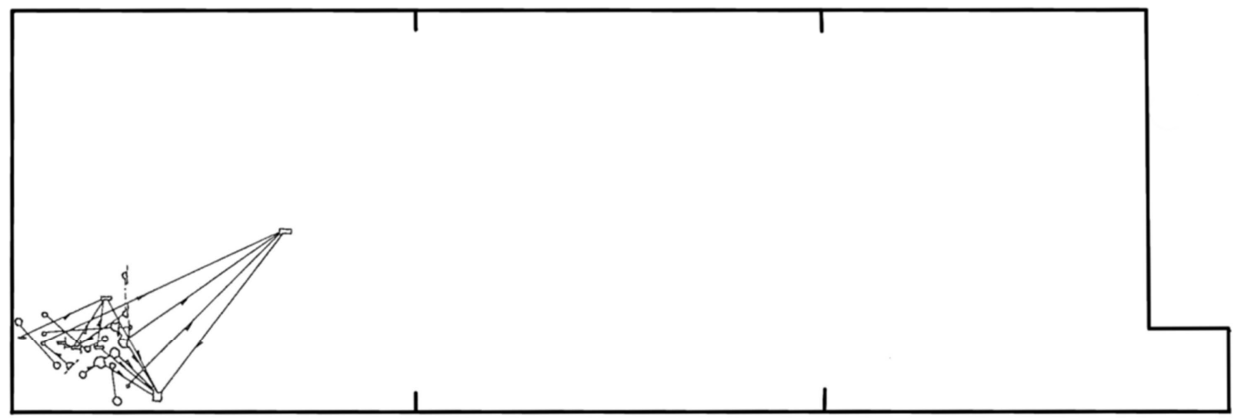

3.

Ryc. 5. Planigrafia pozioma elementów zawartych w składankach ze stanowiska Żuławka 13, gm. Wyrzysk: Blok 1 (1), Blok 6 (2), Blok 7 (3)

Fig. 5. Spatial distribution of the refitted artefacts from Żuławka, site 13, com. Wyrzysk: Block 1 (1), Block 6 (2), Block 7 (3) 


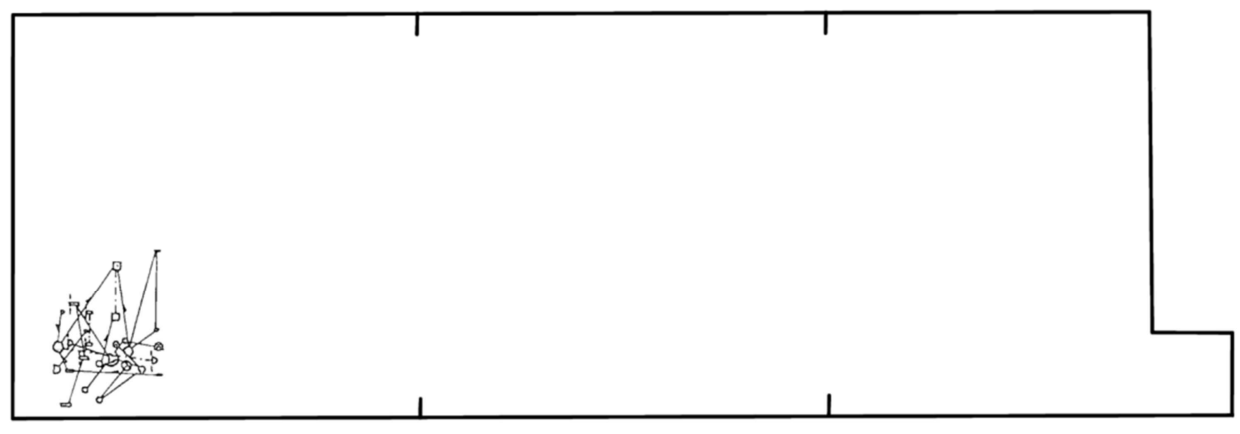

1.

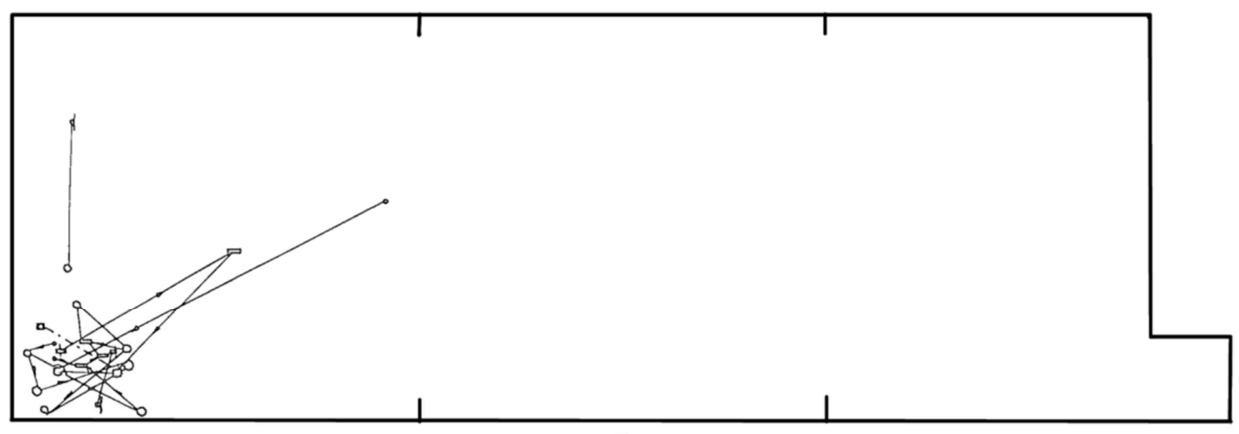

2.

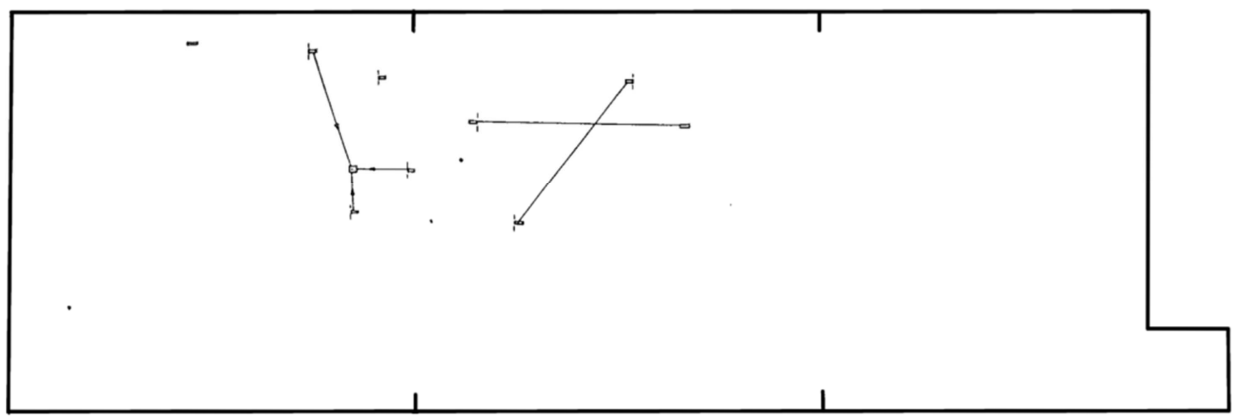

3.

Ryc. 6. Planigrafia pozioma elementów zawartych w składankach ze stanowiska Żuławka 13, gm. Wyrzysk: Blok 8 (1), Blok 9 (2), Blok 14 (3)

Fig. 6. Spatial distribution of the refitted artefacts from Żuławka, site 13, com. Wyrzysk: Block 8 (1), Block 9 (2), Block 14 (3) 


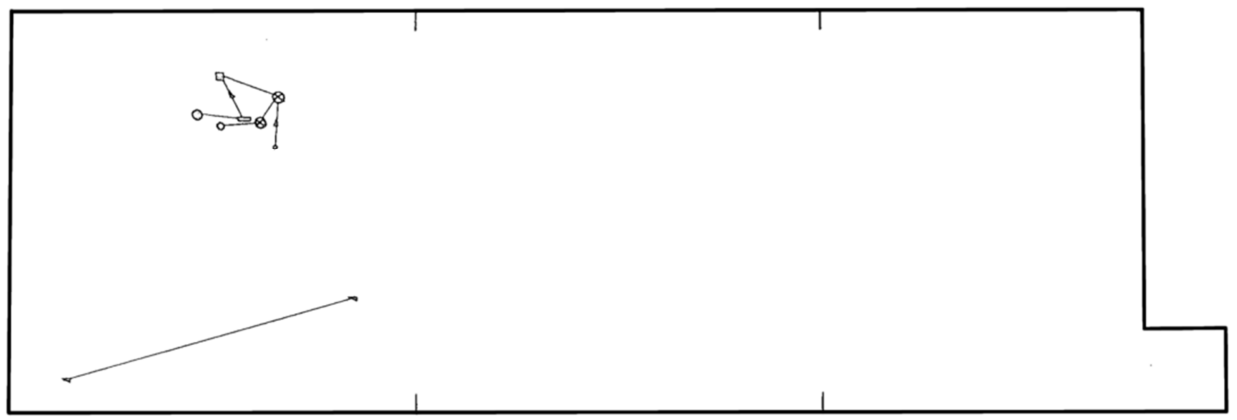

1.

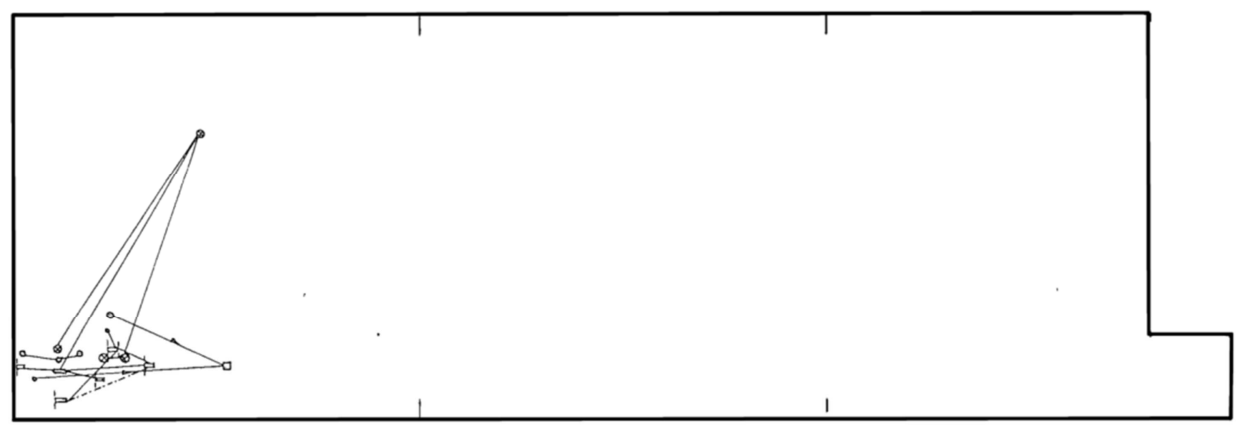

2.

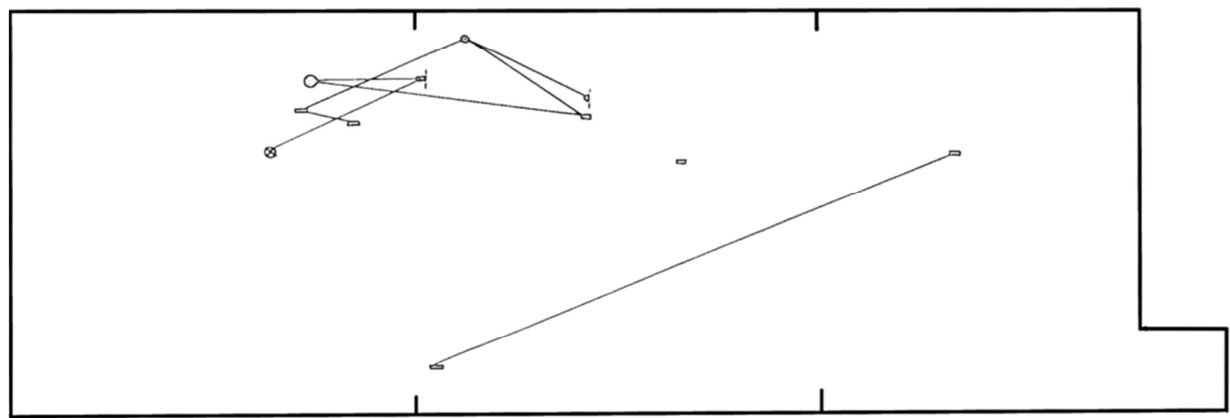

3.

Ryc. 7. Planigrafia pozioma elementów zawartych w składankach ze stanowiska Żuławka 13, gm. Wyrzysk: Blok 15 (1), Blok 10 (2), Blok 20 (3)

Fig. 7. Spatial distribution of the refitted artefacts from Żuławka, site 13, com. Wyrzysk: Block 15 (1), Block 10 (2), Block 20 (3) 